\title{
Production and decomposition of litter in different mahogany (Swietenia macrophylla King) cropping systems
}

\author{
Ruy Guilherme Correia*, Walmer Bruno Rocha Martins, Francisco de Assis Oliveira, Luiz \\ Fernades Silva Dionisio, Raphael Lobato Prado Neves, Telma Fátima Vieira Batista
}

Programa de Pós-Graduação em Ciências Florestais, Universidade Federal Rural da Amazônia, Belém - PA, Brasil.

\begin{abstract}
The objective of this work was to evaluate the litter production and decomposition in three mahogany (Swietenia macrophylla King) systems in the northeastern Pará region. The treatments were: T1 - mahogany consortium with forest species; T2 - homogeneous plantation of mahogany; and T3 - secondary forest enriched with mahogany. Collectors of $1 \mathrm{~m}^{2}$ opening were used to collect the litter produced monthly for a year. Evaluations were performed monthly for one year. The decomposed litter was estimated by means of the relation between the litter produced and the litter accumulated in the soil. The litter deposition dynamics did not present a significant correlation with variations in rainfall and average temperature. The homogeneous mahogany plantation produced more litter $\left(5.6 \mathrm{Mg} \mathrm{ha}^{-1}\right.$ year $\left.^{-1}\right)$ with the leaf fraction being the most representative. The decomposition and renewal of litter did not differ between the three mahogany environments. The pure Brazilian mahogany plantation produced a larger amount of litter compared to the other planting systems, with the leaf fraction presenting the highest percentage contribution.
\end{abstract}

Keywords: nutrient cycling; litterfall deposition; reforestation; ecosystem Services.

\section{Introduction}

Brazil has some one third of the world's remaining tropical forests, but with the impact of human actions on managed environments, important ecosystems are being impacted (DIONISIO et al., 2016; DIONISIO et al., 2017c), principally due to the increase in deforestation rates in the Brazilian Amazon (INPE, 2016).

The search for sustainable production systems has been a key component of development strategies for the Amazon region (LEÃO et al., 2017). However, to manage native forest species successfully, it is necessary to understand the ecological characteristics and dynamics of the species over time so as to know which will be best suited for commercial plantations, reforestation projects or use in the recovery of degraded areas (DIONISIO et al., 2017a; DIONISIO et al., 2017b).

One of these species, mahogany (Swietenia macrophylla King: Meliaceae,), is a semideciduous or deciduous tree found in the Brazilian Amazon (TUCCI et al., 2009). It is notable for its economic potential, especially for its wood, which is in demand for furniture manufacture. Additionally, it is an important species in forest management planning, being one of the most heavily-exploited tree species in Brazil (SILVA et al., 2013).

In addition to the economic benefits gained from the commercialization of mahogany timber, pure or mixed plantations of the species can contribute to the restoration of ecosystem services, including nutrient cycling via the production, accumulation and decomposition of material of organic origin, such as leaves, branches, barks, fruits, seeds, along with the dead bodies of associated fauna, among other residues, that accumulate on the soil surface and in the leaf litter (OLSON, 1963; CUNHA NETO et al., 2013).

Besides functioning as the main route for nutrient transfer to the soil, and from there to the plants, litter also retains rainwater, preventing or minimizing erosive processes (MATEUS et al., 2013). Litter also stores seeds of many species and pro- 
vides shelter to communities of microorganisms that decompose organic matter, thus improving the physical and chemical properties of soil (HOLANDA et al., 2015). For these reasons, the presence of litter is considered an indicator of degraded areas recovery and is the subject of comparative studies between ecosystems (CALDEIRA et al., 2013; CUNHA NETO et al., 2013; SILVA et al., 2015).

Decomposition of litter in tropical moist areas is rapid, due to the high temperatures and constant rains, which favor biological activity and so accelerate the processes of nutrient cycling (ZHANG et al., 2014). However, fluctuations occur in litter production and decomposition. The main biotic factors responsible for this are linked to the composition, structure and age of the contributing vegetation, as well as the phenology of the species involved (SILVA et al., 2009). Abiotic variables also influence the process. These include the pluviometric index, temperature, radiation and soil typology, all of which affect the litter production and decomposition in ecosystems directly (ZHANG et al., 2014).

While studies of the dynamics of litter production and decomposition in plantations of native species, such as mahogany in Amazonia, are important, the subject has been widely neglected. In consequence, the current research had as its objective to evaluate litter production and decomposition in (i) pure mahogany plantations, (ii) mixed plantations of mahogany with other forest species, and (iii) forest at an early stage of succession, in which mahogany had been planted.

\section{Material and Methods}

The study was carried out at the experimental station of Tramontina Belém S.A., Km 102, accessed by BR 010, and located near the city of Aurora do Pará, northeast of the state of Pará (Figure 1), eastern Amazonian Brazil.
According to the Köppen classification, regional climate is Group A, with temperature averaging $25^{\circ} \mathrm{C}$, and annual precipitation between $1,000 \mathrm{~mm}$ and 3,600 $\mathrm{mm}$. Rainfall, although regular, is not evenly distributed across the year (Figure 2), with the period from January to June having about $80 \%$ of the total rainfall volume.

The most common soils in the Aurora do Pará region are Yellow Latosols with medium texture and sandy loam. The average regional altitude is $50 \mathrm{~m}$ above sea level (CORDEIRO et al., 2015). The vegetation of the region is now mostly secondary forests in either early or advanced stages of succession, with important native timer tree having been historically removed by unmanaged logging.

\section{Treatments}

Three cultivation systems were established for the study, given as T1-T3 in Table 1. The ten most common tree species in T3 were: Casearia arborea, Tapirira guianensis, Abarema cochleata, Lecythis lurida, Sapindus saponaria, Myrsia deflexa, Vismia guianensis, Connarus perrottetii, Mabea angustifolia, Cordia exaltata.

Treatments T1 and T2 were planted in 2002 and so were, at the time of study, 13 years old. Before planting, soil analysis was carried out, and the areas subsequently supplemented with limestone $\left(1.5\right.$ ton $\left./ \mathrm{ha}^{-1}\right)$. During planting 400 grams of $\mathrm{N}-\mathrm{P}_{2} \mathrm{O}_{5}-\mathrm{K}_{2} \mathrm{O}$ (18:18:18) was placed in each planting hole. There was no attempt at pest control, with weeds being controlled only with mechanical (tractor) tillage, and no silvicultural treatment was carried out after planting. Each study plot was separated by some $1000 \mathrm{~m}$ from the next. 


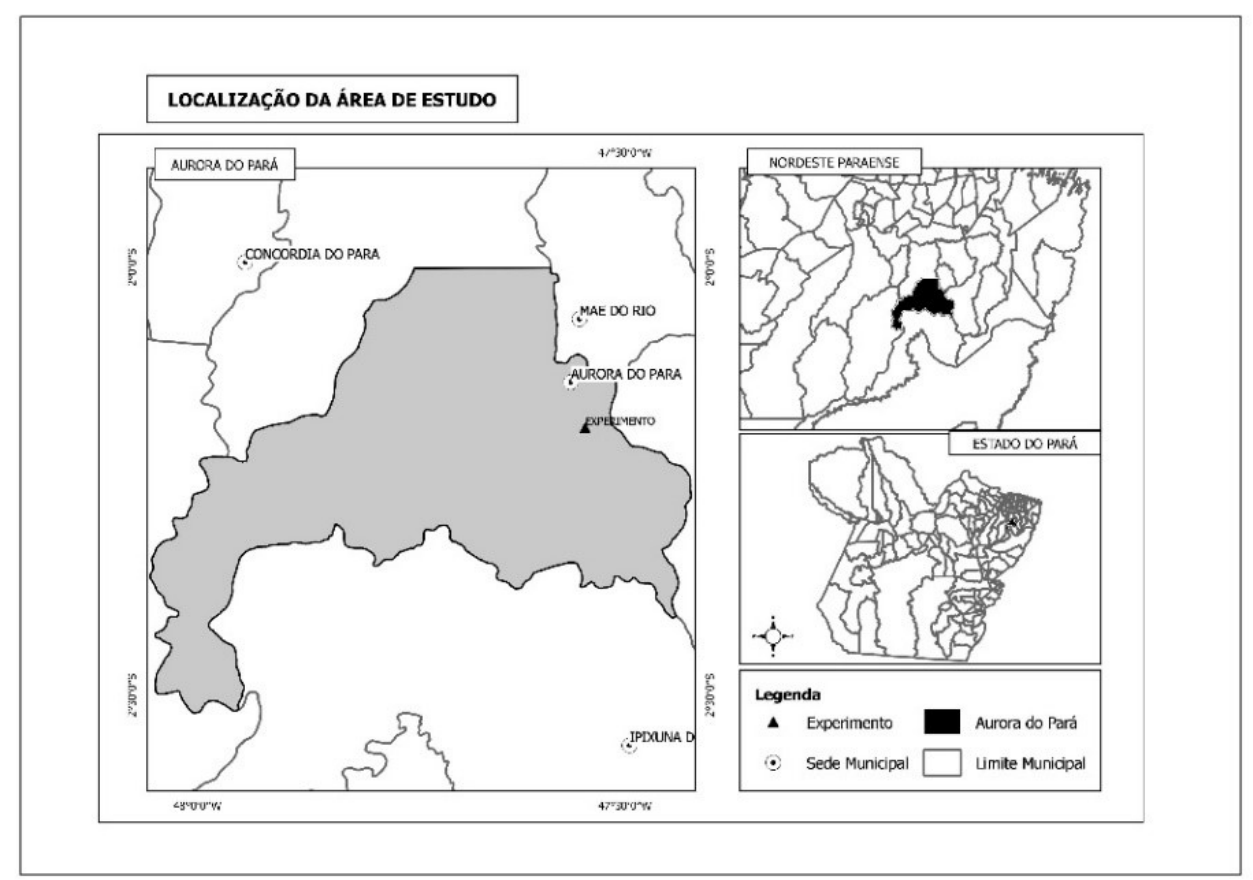

Figure 1. Geographic location of the study area in the municipality of Aurora do Pará, Brazil.

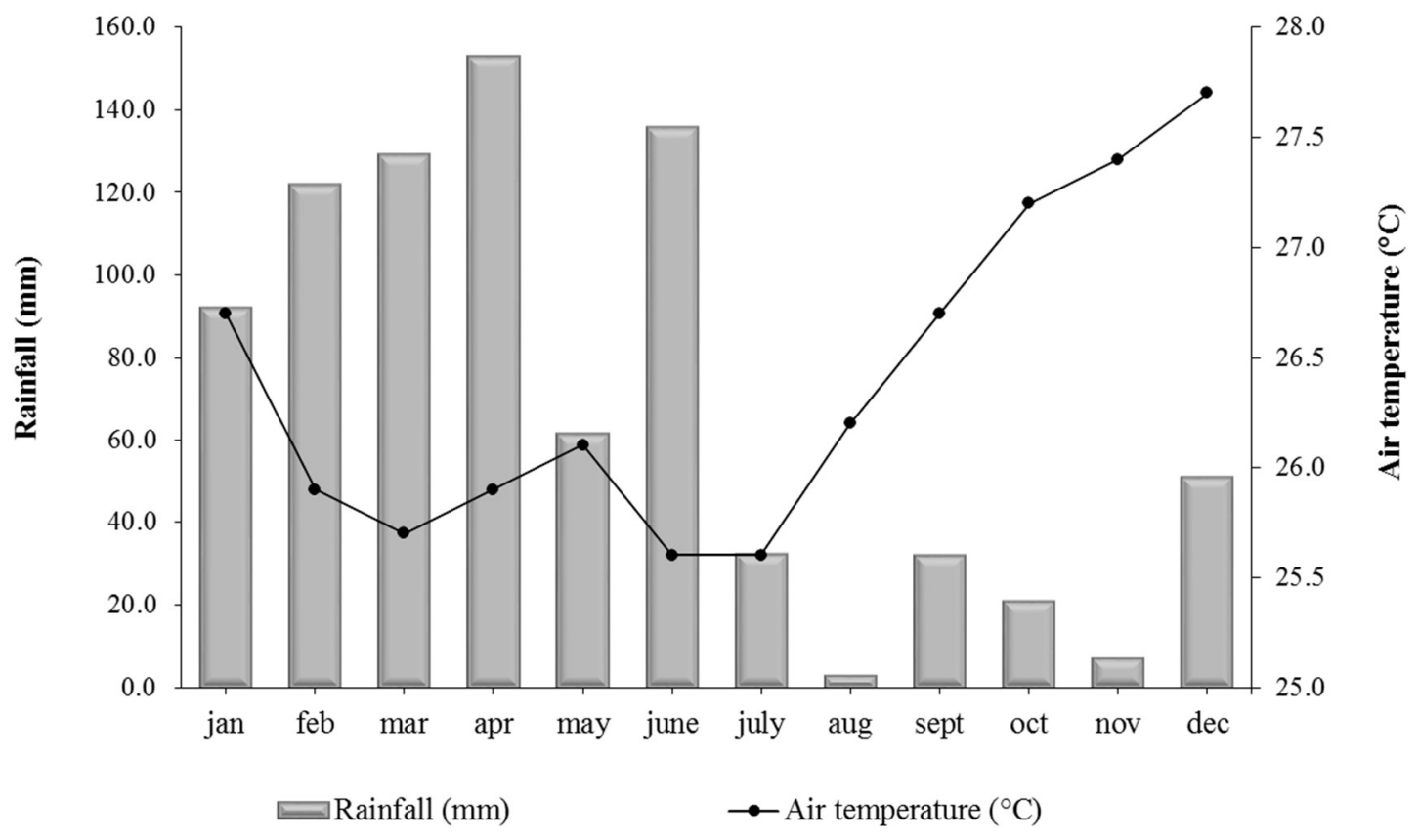

Figure 2. Average temperature and rainfall from January 2014 to December 2016, according to data from the Meteorological Institute (INMET, 2017) in the municipality of Capitão Poço, approximately $60 \mathrm{~km}$ away from the municipality of Aurora do Pará.

\section{Decomposition and litter renewal time}

At the beginning of February, May, August and November of 2015, litter accumulated on the soil surface (with eight collections per treatment) was collected with the aid of a metallic grab with a $0.625 \mathrm{~m}^{2}$ collection area to allow calculation of litter decomposition rates $\left(\mathrm{K}_{\mathrm{L}}\right)$ and renovation times $\left(\mathrm{t}_{\mathrm{R}}\right)$ in each study system, using the equations of Olson (1963) (Equation 1) and Hopkins (1966) (Equation 2), respectively. 
Table 1. Cultivation systems using the Brazilian mahogany (Swietenia macrophylla King.) located in the municipality of Aurora do Pará.

\begin{tabular}{|c|c|c|c|c|}
\hline Treatments & Composition & Spacing & Area (ha) & $\mathrm{N}^{\mathrm{o}}$ indiv. $/ \mathrm{ha}^{-1}$ \\
\hline \multirow{4}{*}{$\mathrm{T} 1$} & Brazilian mahogany (Swietenia macrophylla King.) & $3 \mathrm{~m} \times 3 \mathrm{~m}$ & \multirow{4}{*}{1} & 1111 \\
\hline & Australian ceder (Toona ciliata M. Roemer) & $4 \mathrm{~m} \times 4 \mathrm{~m}$ & & 625 \\
\hline & African mahogany (Khaya ivorensis A. Chev.) & $4 \mathrm{~m} \mathrm{x} 4 \mathrm{~m}$ & & 625 \\
\hline & Neem (Azadiractha indica A. Juss) & $5 \mathrm{~m} \times 5 \mathrm{~m}$ & & 400 \\
\hline $\mathrm{T} 2$ & Brazilian mahogany (Swietenia macrophylla King.) & $3 \mathrm{~m} \times 3 \mathrm{~m}$ & 1 & 1111 \\
\hline T3 & $\begin{array}{l}\text { Native secondary forest in early stages of regeneration, } \\
\text { supplemented with Brazilian mahogany plantings }\end{array}$ & $5 \mathrm{~m} \times 5 \mathrm{~m}$ & 1 & 400 \\
\hline
\end{tabular}

$$
\begin{aligned}
& \mathrm{K}_{\mathrm{L}}=\frac{\mathrm{L}}{\mathrm{X}} \\
& \mathrm{t}_{\mathrm{R}}=\frac{1}{\mathrm{~K}_{\mathrm{L}}}
\end{aligned}
$$

Where: $\mathrm{K}_{\mathrm{L}}=$ coefficient of decomposition; $\mathrm{t}_{\mathrm{R}}=$ mean litter renovation time (years); $\mathrm{L}=$ litter mass produced $\left(\mathrm{Mg} \mathrm{ha}^{-1}\right.$ year $\left.^{-1}\right) ; \mathrm{X}=$ mass of litter accumulated annually $\left(\mathrm{Mg} \mathrm{ha}^{-1}\right)$.

\section{Statistical methods and data analysis}

To analyze the litter production and decomposition, a completely randomized design with measures repeated by time of monthly evaluations for twelve months across eight repetitions was adopted. Results were then analyzed with a D 'Agostino normality test, a Bartlett homogeneity of variance and, later, ANOVA. Means were compared with a Tukey test at $5 \%$ of error probability $(\mathrm{p}<0.05)$. Statistica 8.0 and SigmaPlot 13.0, respectively, were used for statistical analysis and generation of graphs.

\section{Results and Discussion}

Litter was variable and showed no clear trend over time (Figure 3). Annual production values of 4.59, 5.60 4.45 $\mathrm{Mg}$ ha ${ }^{1}$ were recorded from treatments $\mathrm{T} 1, \mathrm{~T} 2$ and $\mathrm{T} 3$ respectively. A number of studies have shown that litter production is higher during periods of lower rainfall, and higher solar radiation and temperatures (BARLOW et al., 2007; SELVA et al., 2007; ZHANG et al., 2014). This occurs because to minimize water loss and control the transpiration process, the majority of forest species lose their leaves, branches and other structures under such conditions (LARCHER, 2004).

Annual litter values in the current study generally appeared low (Table 2) in comparison to those from both other intercropped forest (SILVA et al., 2011; PEREIRA et al., 2017; VILLA et al., 2016), and species-pure plantations (FERNANDES et al., 2006). Mahogany is a climax species and grows slowly in comparison to other species used in plantation monocultures or those selectively planted inside forests showing seasonal leaf-loss or seasonal leaf changes. This may have been a decisive factor for the generally low yield values from the three treatments.

The Leaf and Miscellaneous fractions differed statistically between treatments containing mahogany, with treatment T2 having the highest mean values, as well as the highest monthly litter and annual litter values (Table 2). The density of planting in the species-pure mahogany plantation may have contributed positively to a significant increase in litter production. This is supported by the studies of Alonso et al. (2015) and Villa et al. (2016) who both found greater litter production with denser spacings due to increased competition for resources, especially sunlight. 


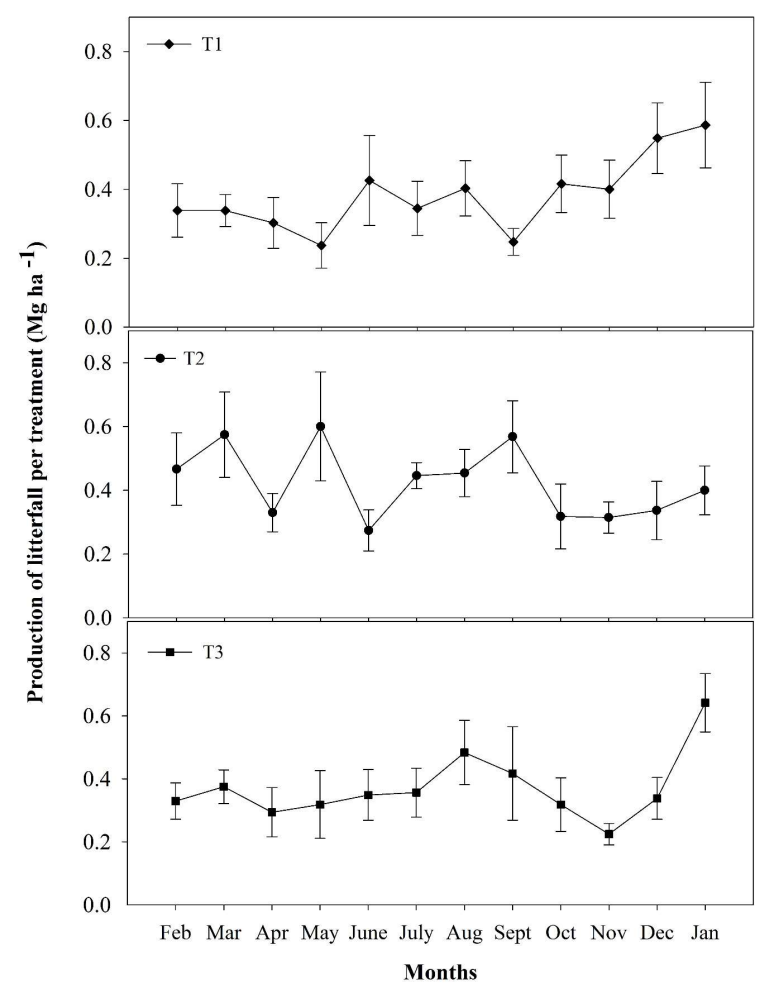

Figure 3. Litterfall during the period from February 2015 to January 2016.

In all three environments studied leaves were the commonest of the four litter fractions, comprising $36 \%, 42 \%$ and $46 \%$ of T1, T2 and T3, respectively (Figure 4). Similar dominance of litter production by leaves has also been reported in other studies conducted in Amazonia (BARLOW et al., 2007; ALMEIDA et al., 2015). Leaves are generally the main constituents of litter and, as they decompose rapidly in forest ecosystems, they form the main route by which nutrients reach the soil (SELLE, 2007). Branches were also an important component. However, since lignin is more resistant to the weather and degrading agents, such materials decompose slowly. As a result, decomposition of branches provides nutrients to the soil in a more gradual and long-term manner (LUIZÃO, 2007).

Mean on-soil litter accumulation rates were $7.58,10.40$ and 7.47 $\mathrm{Mg} \mathrm{ha}^{-1} / \mathrm{year}^{-1}$ for treatments T1, T2 and T3, respectively, with $\mathrm{T} 2$ differing significantly from $\mathrm{T} 1$ and $\mathrm{T} 3$ ( $\mathrm{p}=$ 0.0001). These values were higher than those found by Pereira (2017) in regenerating areas of Paragominas municipality, Pará State. The difference is probably linked to lower decomposition rates at their study site.

Litter accumulation rates in the Amazon region vary between 3.95 and 5.54 $\mathrm{Mg} \mathrm{ha}^{-1}$ year $^{-1}$ for reforested areas, and 4.47 and $9.40 \mathrm{Mg} \mathrm{ha}^{-1}$ year $^{-1}$ for forests in the initial stages of succession (TAPIA-CORAL et al., 2014).

Table 2. Monthly and total annual average of each component of litter.

\begin{tabular}{|c|c|c|c|c|c|c|c|c|c|c|c|c|}
\hline & \multicolumn{3}{|c|}{ Leaves $\left(\mathrm{Mg} \mathrm{ha}^{-1}\right)$} & \multicolumn{3}{|c|}{ Stems $\left(\mathrm{Mg} \mathrm{ha}^{-1}\right)$} & \multicolumn{3}{|c|}{ Repro material $\left(\mathrm{Mg} \mathrm{ha}^{-1}\right)$} & \multicolumn{3}{|c|}{ Miscellaneous. (Mg ha-1) } \\
\hline & $\mathrm{T} 1$ & $\mathrm{~T} 2$ & T3 & $\mathrm{T} 1$ & $\mathrm{~T} 2$ & T3 & $\mathrm{T} 1$ & $\mathrm{~T} 2$ & T3 & $\mathrm{T} 1$ & $\mathrm{~T} 2$ & T3 \\
\hline Feb. & $0,051 \mathbf{b}$ & $0.152 \mathrm{a}$ & $0.078 \mathbf{b}$ & 0.075 & 0.032 & 0.103 & 0.030 & 0.020 & 0.010 & 0.183 & 0.262 & 0.147 \\
\hline Mar. & $0.099 \mathbf{b}$ & $0.332 \mathbf{a}$ & $0.116 \mathbf{b}$ & 0.087 & 0.047 & 0.113 & 0.049 & 0.049 & 0.015 & 0.135 & 0.147 & 0.133 \\
\hline Apr. & $0.051 \mathbf{b}$ & $0.070 \mathbf{b}$ & $0.187 \mathbf{a}$ & 0.075 & 0.103 & 0.064 & 0.015 & 0.007 & 0.019 & 0.161 & 0.151 & 0.024 \\
\hline May & $0.143 \mathbf{b}$ & $0.381 \mathbf{a}$ & $0.241 \mathbf{b}$ & $0.017 \mathbf{b}$ & $0.299 \mathrm{a}$ & $0.017 \mathbf{b}$ & 0.040 & 0.033 & 0.035 & $0.038 \mathbf{b}$ & $0.404 \mathbf{a}$ & $0.027 \mathbf{b}$ \\
\hline Jun. & 0.170 & 0.165 & 0.205 & 0.029 & 0.040 & 0.021 & $0.014 \mathbf{b}$ & $0.026 \mathbf{b}$ & $0.060 \mathrm{c}$ & 0.213 & 0.043 & 0.064 \\
\hline Jul. & $0.051 \mathbf{b}$ & $0.070 \mathbf{b}$ & $0.143 \mathbf{a}$ & 0.075 & 0.103 & 0.018 & 0.037 & 0.106 & 0.169 & 0.181 a & 0.168 a & $0.028 \mathbf{b}$ \\
\hline Aug. & 0.190 & 0.198 & 0.143 & 0.053 & 0.019 & 0.050 & $0.083 \mathbf{b}$ & $0.130 \mathbf{b}$ & $0.256 \mathbf{a}$ & $0.078 \mathbf{a b}$ & 0.108 a & $0.034 \mathbf{b}$ \\
\hline Sept. & $0.100 \mathbf{b}$ & $0.257 \mathbf{a b}$ & $0.327 \mathbf{a}$ & 0.072 & 0.063 & 0.021 & 0.029 & 0.029 & 0.031 & $0.047 \mathbf{b}$ & $0.219 \mathbf{a}$ & $0.038 \mathbf{b}$ \\
\hline Out. & 0.170 & 0.230 & 0.205 & $0.165 \mathrm{a}$ & 0.019 b & $0.017 \mathbf{b}$ & 0.036 & 0.050 & 0.047 & 0.046 & 0.019 & 0.050 \\
\hline Nov. & 0.143 a & $0.070 \mathbf{a b}$ & $0.051 \mathbf{a}$ & 0.075 & 0.055 & 0.103 & 0.017 & 0.040 & 0.050 & 0.166 & 0.150 & 0.021 \\
\hline Dec. & 0.229 & 0.217 & 0.182 & $0.125 \mathrm{a}$ & $0.061 \mathbf{a b}$ & $0.068 \mathbf{b}$ & 0.171 a & $0.052 \mathbf{b}$ & $0.055 \mathbf{b}$ & 0.023 & 0.008 & 0.034 \\
\hline Jan. & 0.274 & 0.198 & 0.174 & 0.060 & 0.019 & 0.045 & 0.152 & 0.118 & 0.153 & $0.101 \mathbf{b}$ & $0.065 \mathbf{a b}$ & $0.271 \mathbf{a}$ \\
\hline
\end{tabular}

Values with equal letters in the line for each component of the litter do not differ statistically (Tukey test, $5 \%$ of probability of error: $\mathrm{p}<0.05)$. 


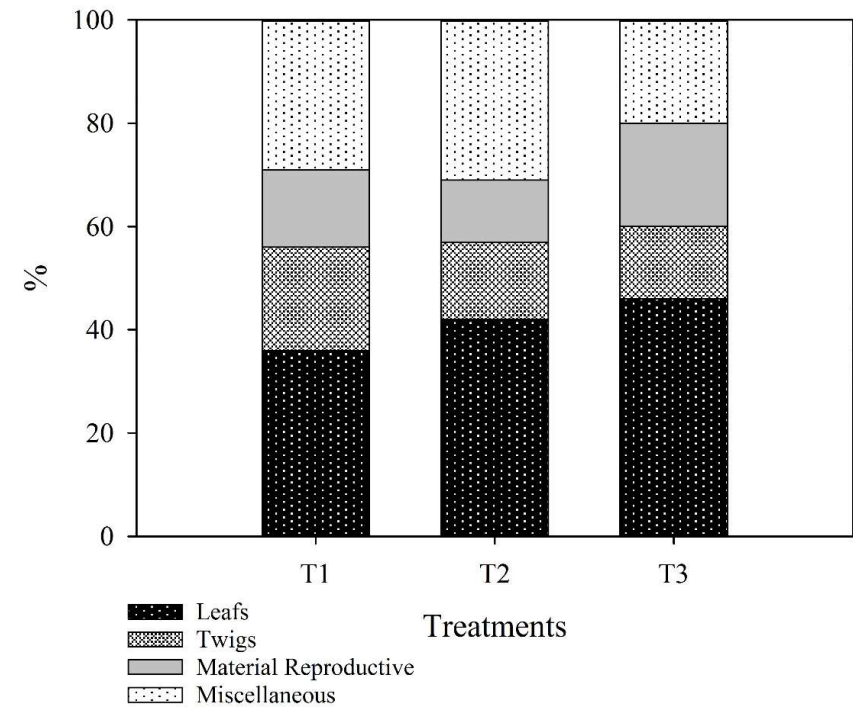

Figure 4. Percentage and components of litter in each treatment.

The decomposition coefficient ' $\mathrm{K}_{\mathrm{L}}$ ' and the renewal time of the ' $t$ ' litter showed strongly differing values (Table 3 ). Normally, litter decomposition values in tropical forests are greater than 1 and less than 4 , indicating a state of dynamic equilibrium, and rapid renewal (OLSON, 1963). The low decomposition rates recorded in the three treatments may be related to the low levels of rainfall during the study period. Both Kozovits et al. (2007) and Holland et al. (2015) consider that water is key to promoting swift litter component breakdown, as it directly assists in the multiplication of populations of micro- and meso-organisms, as well as macrofaunal decomposers.

Table 3. Decomposition rate and litter renewal time in the three treatments.

\begin{tabular}{lcc}
\hline \multirow{2}{*}{ Treatments } & $\begin{array}{c}\text { Decomposition } \\
\text { Coeffecient }\end{array}$ & $\begin{array}{c}\text { Renovation } \\
\text { Time }\end{array}$ \\
\cline { 2 - 3 } & $\mathrm{K}_{\mathrm{L}}$ & $\mathrm{t}$ (years) \\
\hline $\mathrm{T} 1$ & 0.71 & 1.41 \\
$\mathrm{~T} 2$ & 0.93 & 1.08 \\
$\mathrm{~T} 3$ & 0.62 & 1.61 \\
\hline$p$-value & 0.9487 & 0.9487 \\
\hline
\end{tabular}

Time required for litter renewal was high; in each treatment it would require more than a year for the material present to be fully decomposed. Litter replacement was highest in $\mathrm{T} 2$ but did not differ significantly from $\mathrm{T} 1$ and $\mathrm{T} 3$. These results were expected since Brazilian mahogany, a species present in all three study environments, contributes to more extensive litter formation; in consequence, values for decomposition rates and renewal times are similar between treatments due to the dominance of the same source material.

\section{Conclusions}

Litter production, decomposition rate and renewal time of Brazilian mahogany were low and did not show a difference between the study environments. Since only one year is likely to have been insufficient to study these variables fully, they should be evaluated over a longer period.

\section{References}

ALMEIDA, E. J.; LUIZÃO, F.; RODRIGUES, D. J. Produção de serrapilheira em florestas intactas e exploradas seletivamente no sul da Amazônia em função da área basal da vegetação e da densidade de plantas. Acta Amazonica, v.45, n.2, p.157-166, 2015.

ALONSO, J. M.; LELES, P. S. S.; FERREIRA, L. N.; OLIVEIRA, N. S. A. Aporte de serapilheira em plantio de recomposição florestal em diferentes espaçamentos. Ciência Florestal, v.25, n.1, p.1-11, 2015.

BARLOW, J.; GARDNER, T. A.; FERREIRA, L. V.; PERES, C. A. Litter fall and decomposition in primary, secondary and plantation forests in the Brazilian Amazon. Forest Ecology and Management, v.247, n.1, p.91-97, 2007.

CALDEIRA, M. V. W.; SILVA, R. D.; KUNZ, S. H.; ZORZANELLI, J. P. F.; CASTRO, K. C.; GODINHO, T. O. Biomassa e nutrientes da serapilheira em diferentes coberturas florestais. Comunicata Scientiae, v.4, n.2, p.111-119, 2013.

CORDEIRO, I. M. C. C.; BARROS, P. L. C.; LAMEIRA, O. A.; GAZEL FILHO, A. B. Avaliação de plantios de paricá (Shi- 
zolobium parahyba var. amazonicum (Huber ex Ducker) Barney de diferentes idades e sistemas de cultivo no município de Aurora do Pará - PA (Brasil). Ciência Florestal, v.25, n.3, p.679-687, 2015.

CUNHA NETO, F. V.; LELES, P. S. S.; PEREIRA, M. G.; BELLUMATH, V. G. H.; ALONSO, J. M. Acúmulo e decomposição da serapilheira em quatro formações florestais. Ciência Florestal, v.23, n.3, p.379-387, 2013.

DIONISIO, L. F. S.; BONFIM FILHO, O. S.; CRIVELLI, B. R. S.; GOMES, J. P.; OLIVEIRA, M. H. S.; CARVALHO, J. O. P. Importância fitossociológica de um fragmento de floresta ombrófila densa no estado de Roraima, Brasil. Revista Agro@mbiente On-line, v. 10, n. 3, p. 243-252, 2016.

DIONISIO, L. F. S.; CONDÉ, T. M.; GOMES, J. P.; MARTINS, W. B. R.; SILVA, M. T.; SILVA, M. W. Caracterização morfométrica de árvores solitárias de Bertholletia excelsa HBK no sudeste de Roraima. Revista Agro@mbiente Online, v. 11, n. 2, p. 163-173, 2017b.

DIONISIO, L. F. S.; SCHWARTZ, G.; LOPES, J. C.; SANTOS, G. G. A.; OLIVEIRA, F. A. Mortality of stocking commercial trees after reduced impact logging in eastern Amazonia. Forest Ecology Management v. 401, p. 1-7, 2017c.

DIONISIO, L. F. S.; SMIDERLE, O. J.; MONTENEGRO, R. A.; MARTINS, W. B. R.; SIMÕES, P. H. O.; ARAÚJO, D. G. Emergência e crescimento inicial de plântulas de Swietenia macrophylla (King) em função da posição da semente e presença do endocarpo. Revista de Ciências Agrárias, v. 60, n. 2, p. 125-130, 2017a.

FERNANDES, M. M.; PEREIRA, M. G.; MAGALHÃES, L. M. S.; CRUZ, A. R.; GIÁCOMO, R. G. Aporte e decomposição de serapilheira em áreas de floresta secundária, plantio de sabiá (Mimosa caesalpiniaefolia benth.) e andiroba (Carapa guianensis aubl.) na Flona Mário Xavier, RJ. Ciência Florestal, v.16, n.2, p.163-175, 2006

HOLANDA, A. C.; FELICIANO, A. L. P.; MARANGON, L. C.; FREIRE, F. J.; HOLANDA, E. M. Decomposição da serapilheira foliar e respiração edáfica em um remanescente de caatinga na Paraíba. Revista Arvore, v.39, n.2, p.245-254, 2015.

HOPKINS, B. Vegetation of the Olkemeji Forest Reserve, Nigeria. IV: The litter and soil with special reference to their seasonal changes. Journal of Ecology, v.54, p.687-703, 1966.
INSTITUTO NACIONAL DE METEOROLOGIA - INMET. $2^{\circ}$ Distrito de Meteorologia, consulta genérica. Estação automática A248 Capitão Poço/PA. Serviço Nacional de Informações Hidro Meteorológicas - SIM. Disponível em: http://www.inmet. gov.br/climatologia. Acesso em 20 outubro 2017.

INSTITUTO NACIONAL DE PESQUISAS ESPACIAIS INPE. Monitoramento da Floresta Amazônica Brasileira por Satélite (Projeto Prodes). 104p. Disponível em <http://www.obt.inpe.br/prodes/prodes_1988_2015.htm>. Acesso em 10 de dezembro de 2016.

KOZOVITS, A. R.; BUSTAMANTE, M. M. C.; GAROFALO, C. R.; BUCCI, S.; FRANCO, A. C.; GOLDSTEIN, G. MEINZER, F. C. Nutrient resorption and patterns of litter production and decomposition in a Neotropical Savanna. Functional Ecology, v.21, n.6, p.1034-1043, 2007.

LARCHER. W. Ecofisiologia vegetal. São Carlos: RIMA, 2004. 531p.

LEÃO, F. M.; DIONISIO, L. F. S.; SILVA, N. G. E.; BARBOSA, L. M.; OLIVEIRA, M. H. S.; NEVES, R. L. P. Fitossociologia em sistemas agroflorestais com diferentes idades de implantação no município de Medicilândia, PA. Revista Agro@mbiente On-line, v. 11, n. 1, p. 71-81, 2017.

LUIZÃO, F. J. Ciclos de nutrientes na Amazônia: respostas às mudanças climáticas. Ciência e Cultura, v.59, n.3, p.31-36, 2007.

MATEUS, F. A.; MIRANDA, C. C.; VALCARCEL, R.; FIGUEIREDO, P. H. A. Estoque e capacidade de retenção hídrica as serrapilheira acumulada na restauração florestal de áreas perturbadas na Mata Atlântica. Floresta e Ambiente, v.20, n.3, p.336-343, 2013.

OLSON, J. S. Energy storage and the balance of producers and decomposers in ecological systems. Ecology, v.44, n.2, p.322331, 1963.

PEREIRA, D. N; MARTINS, W. B. R; ANDRADE, V. M. S. DE; OLIVEIRA, F. A. Influência da remoção de serapilheira no teor de fósforo e potássio na Amazônia Oriental. Revista Brasileira de Ciências Agrárias. v.12, n.3, p.380-385, 2017.

SELLE, G. L. Ciclagem de nutrientes em ecossistemas florestais. Bioscience Journal, v. 23, n. 4, p. 29-39, 2007. 
SELVA, E. C.; COUTO, E. G.; JOHNSON, M. S.; LEHMANN, J. Litterfall production and fluvial export in headwater catchments of the southern Amazon. Journal of Tropical Ecology, v.23, n.3, p.329-335, 2007.

SILVA, A. K. L.; VASCONCELOS, S. S.; CARVALHO, C. J. R.; CORDEIRO, I. M. C. C. Litter dynamics and fine root production in Schizolobium parahyba var. amazonicum plantations and regrowth forest in Eastern Amazon. Plant Soil, v.347, n.1, p.347-377, 2011.

SILVA, C. F.; CARMO, E. R.; MARTINS, M. A.; FREITAS, M. S. M.; PEREIRA, M. G.; SILVA, E. M. R. Deposition and nutritional quality of the litter of pure stands of Eucalyptus camaldulensis and Acacia mangium. Bioscience Journal, v.31, n.4, p.1081-1091, 2015.

SILVA, M. C. A.; ROSA, L. S.; VIEIRA, T. A. Eficiência do nim (Azadirachta indica A. Juss) como barreira natural ao ataque de Hypsipyla grandella (Zeller) (Lepidoptera: Pyralidae) sobre o magno (Swietenia macrophylla King). Acta Amazonica, v.43, n.1, p.19-24, 2013.

SILVA, R. M.; COSTA, J. M. N.; RUIVO, M. L. P.; COSTA, A. C. L.; ALMEIDA, S. S. Influência de variáveis meteorológicas na produção de liteira na Estação Científica Ferreira Penna, Caxiuanã, Pará. Acta Amazonica, v.39, n.3, p.573$582,2009$.

TAPIA-CORAL, S.C.; LUIZÃO, F.; PASHANASI, B.; CASTILLO, D. D.; LAVELLE, P. Influência da massa e nutrientes da liteira sobre a composição dos macro-invertebrados em plantios florestais na Amazônia peruana. Revista científica Folia Amazónica, v.23, n.2, p.171-186, 2014.

TUCCI, C. A. F.; LIMA, H. N.; LESSA, J. F. Adubação nitrogenada na produção de mudas de mogno (Swietenia macrophylla King). Acta Amazonica, v. 39, n. 2, p. 289-294, 2009.

VILLA, E. B.; PEREIRA, M. G.; ALONSO, J. M.; BEUTLER, S. J.; LELES, P. S. S. Aporte de serapilheira e nutrientes em área de restauração florestal com diferentes espaçamentos de plantio. Floresta e Ambiente, v.23, n.1, p.90-99, 2016.

ZHANG, H. YUAN, W.; DONG, W.; LIU, S. Seasonal patterns of litterfall in forest ecosystem worldwide. Ecological Complexity, v.20, p.240-247, 2014. 